Indonesian Journal of Islamic Psychology

Volume 2. Number 1, June 2020 (p-ISSN: 2685-1482 e-ISSN 2714-7576)

website: http://e-journal.iainsalatiga.ac.id/index.php/ijip/index

\title{
Memahami Kecemasan: Perspektif Psikologi Islam
}

\section{Aditya Dedy Nugraha ${ }^{1 *}$}

UIN Sunan Kalijaga Yogyakarta, Indonesia

\begin{abstract}
Anxiety has always been an interesting topic, how anxiety can be the entrance to other personality disorders and how humans are able to adapt to overcome anxiety into a research theme that remains hot to study. This study examines what anxiety is, how previous research is able to overcome anxiety. This study uses two perspectives, namely psychology in general and Islamic psychology in particular Islamic Psychotherapy. This study uses the literature review method, which originated from Garuda (Digital Reference Garba) from the KemenristekBrin, to study what techniques can reduce anxiety. The results obtained that in addition to psychotherapy, Islamic psychotherapy has also begun to be used to reduce individual anxiety levels.
\end{abstract}

Keywords: anxiety; psychotherapy; Islamic psychotherapy; Islamic psychology

\begin{abstract}
Abstrak
Kecemasan selalu menjadi topik yang menarik, bagaimana kecemasan dapat menjadi pintu masuk menuju gangguan kepribadian lainnya dan bagaimana manusia mampu beradaptasi mengatasi kecemasan menjadi tema riset yang tetap hangat untuk dikaji. Penelitian ini mengkaji apa itu kecemasan, bagaimana penelitian terdahulu mampu mengatasi kecemasan. Penelitian ini menggunakan dua sudut pandang, yaitu psikologi secara umum dan psikologi Islam khususnya Psikoterapi Islam. Penelitian ini menggunakan metode literature reviews, yang berasal dari Garuda (Garba Rujukan Digital) dari Kemenristek-Brin, untuk dikaji teknik apa saja yang bisa menurunkan kecemasan. Hasilnya diperoleh bahwa selain psikoterapi, psikoterapi Islam juga sudah mulai digunakan untuk menurunkan tingkat kecemasan individu.
\end{abstract}

Kata Kunci: kecemasan; psikoterapi; psikoterapi Islam; psikologi Islam 
Pendahuluan

Age of anxiety istilah yang umum kita dengar mengenai kecemasan, yakni masa atau abad yang penuh kecemasan. Apalagi mengingat pandemi covid19 yang menambah keyakinan kita akan istilah umum tersebut. Informasi yang tidak jelas sumbernya menambah rasa panik, takut dan cemas dalam masyarakat. Covid 19 menimbulkan kecemasan karena masyarakat menyesuaikan dan banyak pola hidup yang baru (Republika, 2020). Psikologi memandang kecemasan sendiri beranekaragam, banyak teori dan teknik diteliti serta dikembangkan untuk mengatasi permasalahan kecemasan ini. Kecemasan menjadi topik yang tidak pernah sepi untuk diteliti, karena kecemasan menjadi awal masuk untuk mendiagnosa beberapa gangguan kepribadian lainnya. Kecemasan sendiri seringkali bukan hal yang berat, tergantung pada kondisi yang dialami tiap individu, namun bukan hal yang ringan pula. Seseorang yang sedang mengalami kecemasan bisa mengalami kehilangan konsentrasi dan kurang optimal dalam mengerjakan sesuatu.

Kecemasan kita akhir-akhir ini lebih kepada mengkhawatirkan akan sesuatu hal yang belum tentu terjadi, apalagi dengan situasi pandemic seperti sekarang ini. Keadaan masyarakat seperti ini sesuai dengan pendapat yang pernah dikemukakan oleh (Bastaman, 2011), bahwa kecemasan yang terjadi sekarang ini lebih bergeser kepada bagaimana individu mengalami kehampaan hidup. Lebih lanjut dikatakan bahwa untuk mengatasi hal tersebut maka diperlukan cara untuk menemukan 'makna' hidup bagi seseorang.

Sebuah hal yang wajar jika tiap individu pernah mengalami kecemasan, dalam situasi tertentu, terkadang sebuah situasi menyebabkan kecemasan bagi seseorang namun merupakan hal yang dianggap biasa saja bagi individu lainnya, misalnya kecemasan ketika 
akan mengahadapi lingkungan yang baru bagi sebagian mahasiswa lingkungan yang baru menjadi penyebab kecemasan (Rohmadani, 2019), namun lingkungan yang baru juga menjadi hal yang biasa saja bagi siswa lainnya. Penyebab utama kecemasan yang berbeda-beda itu menurut beberapa ahli Psikologi, dikarenakan adanya perbedaan sudut pandang dalam menganalisa apa yang melatarbelakangi individu bisa mengalami kecemasan. Kecemasan dalam kacamata psikologi sosial, hal ini diakibatkan karena individu takut mengalami penolakan atau ketakutan akan tidak diterima oleh kelompok atau masyarakat (Burger, 2011). Sebagai contoh ketika seseorang akan tampil atau berpidato di depan khalayak, maka beberapa individu mengalami kecemasan, jika kita analisa lebih mendalam penyebabnya bisa saja terjadi karena individu tersebut takut dikoreksi atau pidatonya tidak diterima oleh khalayak umum, maka respon fisik yang dimunculkan biasanya bergetar, suara terbata-bata atau keringat dingin atau respon kecemasan lainnya.

Kecemasan yang dialami manusia sekarang ini juga dialami oleh pendahulu kita, dan menjadi bukti bahwa manusia dalam pandangan teori penyesuaian kepribadian mampu beradaptasi dalam situasi yang menciptakan kecemasan itu dan berhasil melaluinya (Burger, 2011). Beberapa ilmuwan psikologi terutama di Indonesia mengkaji mengenai kecemasan dan berbagai upaya untuk mengatasinya. Jika kita telusur melalui google scholar dengan kata kunci kecemasan maka akan muncul ribuan penelitian terbaru mengenai hal ini.

\section{Kecemasan}

Manusia mempunyai penyebab kecemasannya masing-masing. Ada yang cemas saat akan ujian, akan tampil di depan kelas, ada yang cemas dengan lingkungan yang baru, adapula yang cemas akan apa yang belum 
dia hadapi. Cemas atau sering disebut anxietas yaitu perasaan khawatir, takut yang penyebabnya tidak pasti. Kecemasan adalah reaksi yang tepat terhadap suatu hal yang dianggap mengancam, namun cemas menjadi tidak wajar apabila reaksi dan kemunculannya tidak tepat, baik intensitas maupun tingkatan gejalanya (Nevid et al., 2005). Kecemasan dialami oleh semua orang dalam perjalanan kehidupannya. Kecemasan adalah hal yang lumrah dialami individu, terutama saat ia merasa tertekan dalam hidupnya. Kecemasan dapat timbul dengan sendirinya atau munculnya tergabung disertai gejala-gejala dari berbagai gangguan emosi yang lain (Ramaiah, 2003). Kecemasan adalah suatu dorongan yang kuat terhadap perilaku, baik perilaku yang kurang sesuai ataupun perilaku yang menganggu. Keduanya merupakan manifestasi dari pertahanan terhadap kecemasan tersebut (Gunarsa, 2008). Kecemasan merupakan reaksi pada keadaan tertentu yang dirasa menjadi ancaman, dan merupakan sesuatu yang lumrah terjadi menyertai perkembangan, perubahan, peristiwa baru maupun yang belum pernah dilakukan, juga dalam menemukan jati diri dan makna hidup (Kaplan, H.I, Grebb, BA, and Sadock, 2010).

Kecemasan menurut (Sarwono, 2017) menyebutkan bahwa masyarakat Indonesia pada umumnya menyebut pobhia, fear, dan anxiety menjadi satu kata yaitu 'takut', padahal semua kata tersebut memilik makna yang berbeda. Lebih lanjut dijelaskan bahwa pobhia adalah rasa takut yang tidak rasional pada objek dan situasi tertentu (Fieldman 2003, dalam (Sarwono, 2017), dengan pengertian bahwa objek yang dialami memang nyata adanya namun alasan yang mendasari untuk takut itu tidak rasional. Takut atau fear adalah keadaan emoasi yang tidak menyenangkan. Kecemasan ialah saat individu mengalami 
cemas yang objeknya tidak bisa dipastikan dan alasannya pun tidak begitu jelas. Dari uraian ini bisa kita bedakan antara fobia dan kecemasan perbedaannya terletak pada objeknya, jika objek fobia adalah nyata dan jelas, namun objek kecemasan itu tidak jelas. Senada dengan penjelasan di atas (Mujib, 2017) menjelaskan anxiety (kecemasan) terhadap sesuatu yang tidak jelas, merupakan simptom dari kepribadian "was-was".

Kecemasan juga bisa diartikan sebagai suatu sistem ego dalam diri manusia terhadap suatu situasi yang dianggap membahayakan sehingga manusia bisa mempersiapkan reaksi yang adaptif (Alwisol, 2008). Kecemasan sendiri menurut kajian psikologi islam, merujuk di dalam Al-Qur'an dijelaskan sebagai emosi takut. Lebih lanjut Abdul Hasyim dalam (Cahyandari, 2019) menjelaskan bahwa kata khassyah dan derivasinya dalam Al-Quran disebutkan sebanyak 39 kali. Takut disini lebih kepada arti takut kepada Allah SWT, takut akan siksa, takut tidak mendapatkan Ridha-Nya. Dalam ayat Al-Qur'an pada surat AlBaqarah 155 juga dijelaskan bahwa manusia akan diuji dengan ketakutan yang arti ayatnya adalah sebagai berikut:

"Dan Kami pasti akan menguji kamu dengan sedikit ketakutan, kelaparan, kekurangan harta, jiwa, dan buah-buahan. Dan sampaikanlah kabar gembira kepada orang-orang yang sabar, (QS. Al-Baqarah: 155)”.

Kesimpulan yang bisa diambil dari penjelasan pengertianpengertian kecemasan di atas bahwa kecemasan yang menjadi pembahasan dalam penelitian ini memiliki makna takut yang irrasional, dan dialami semua individu serta merupakan respon alami individu atas suatu peristiwa, reaksi emosi takut itu membuat perasaan yang tidak nyaman, sehingga bisa bermanifestasi terhadap perilaku individu tersebut. 
Aditya Dedy Nugraha

Jenis - Jenis Kecemasan ada tiga menurut Freud dalam (Rahman, 2020) yaitu : a. Kecemasan Realitas atau Objektif (Reality of Objective anxiety) b. Kecemasan Neorosis (Neurotic Anxiety) c. Kecemasan Moral.

\section{Aspek-aspek Kecemasan}

Gejala kecemasan meliputi respon fisik dan psikologis. Adanya rasa khawatir dan diikuti rasa gelisah, berakibat pada respon fisiologis tertentu. Beberapa individu mampu mengatasinya namun ada beberapa yang kesulitan menanganinya. Berikut aspek kecemasan menurut Clark dan Beck dalam (Fadila, 2018) disebutkan bahwa aspek kecemasan meliputi; Aspek afektif : yaitu perasaan individu yang sedang merasakan kecemasan, seperti tersinggung, gugup, tegang, gelisah, kecewa dan tidak sabar. Aspek Fisiologis: merupakan ciri fisik yang muncul ketika individu sedang mengalami kecemasan, seperti sesak nafas, nyeri dada, nafas menjadi lebih cepat, denyut jantung meningkat, mual, diare, kesemutan, berkeringat, menggigil, kepanasan, pingsan, lemas, gemetar, mulut kering dan otot tegang. Aspek selanjutnya yaitu meliputi aspek Kognitif: dengan ciri aspek kognitif yaitu rasa takut tidak dapat menyelasaikan masalah, takut mendapatkan komentar negatif, kurangnya perhatian, fokus, dan kurangnya konsentrasi, sulit melakukan penalaran. Aspek Perilaku: respon yang biasanya muncul adalah menghindari situasi yang mengancam, mencari perlindungan, diam, banyak bicara atau terpaku, dan sulit bicara. Bisa kita tarik kesimpulan bahwa aspek perilaku meliputi semua sisi dalam diri manusia, baik sisi afektif, kognitif maupun psikomotorik individu yang sedang mengalai kecemasan.

Berbagai simptom atau gejala yang muncul saat seseorang mengalami kecemasan juga dijelaskan oleh Santoso dkk, 1998 dalam (Julianto et al., 2018) gejala fisik ditunjukan dengan tangan 
mengeluarkan keringat, irama detak jantung lebih cepat, dan kaki gemetaran, sedangkan gejala secara psikologis biasanya muncul dengan tidak dapat berkonsentrasi dan perasaan yang tidak tenang. Dalam penelitian ini lebih menitikberatkan pada kecemasan berbicara di hadapan penonton atau di depan publik yang dapat muncul karena perasaan rendah diri, kurang menarik serta tidak menyenangkan bagi orang lain.

Gejala fisik yang sering muncul secara intensif jika individu mengalami kecemasan seperti mengeluarkan keringat dingin, irama detak jantung lebih cepat (berdebar-debar), sakit kepala, tekanan darah mengalami kenaikan, susah tidur, gelisah, dan gejala lainnya (Sarwono, 2017). Gejala lain dikemukakan oleh (Yusuf, 2018) terlihat pada perubahan kinerja anggota tubuh, yakni denyut jantung menjadi lebih cepat, gangguan pernapasan, mengeluarkan keringat berlebih, dan lainnya. Karena sesungguhnya kecemasan ialah respon kita dalam menyadari sebuah ancaman (threat) yang objeknya belum pasti.

\section{Faktor penyebab kecemasan}

Kecemasan bisa berasal dari faktor internal dan eksternal seseorang, beberapa ahli menjelaskan lebih rinci dengan penjabaran sebagai berikut : dalam (Ramaiah, 2003) menjelaskan bahwa Faktor pertama yakni; Lingkungan dimana kita tinggal memberi warna pola berfikir sesorang mengenai diri sendiri ataupun orang lain. Peristiwa ini dikarenakan ada peristiwa dan pengalaman yang kurang menyenangkan pada seseorang terhadap keluarga, teman, atau dengan teman kerja. Hingga seseorang tersebut merasa insecure terhadap lingkungan tempat tinggalnya. Selanjutnya faktor ke dua adalah Perasaan yang tidak diungkapkan dan direpress. Kecemasan dapat aktual apabila seseorang 
kurang mampu menemukan solusi untuk perasaannya sendiri, terutama jika dirinya merepress perasaan marahnya atau frustasi dalam tempo yang amat lama. Yang ke tiga adalah semual hal mengenai tubuh dan pikiran selalu saling terhubung dan mampu menimbulkan kecemasan. Peristiwa ini akan aktual pada peristiwa-peristiwa dalam kehidpuan seperti pada saat hamil, sewaktu remaja dan saat pulih dari sebuah penyakit. Setelah mengalami peristiwa tersebut diatas, sebuah hal yang lumrah apabila muncul kecemasan pada seseorang.

Pendapat ahli lain mengenai faktor yang dapat menyebabkan kecemasan ada 3 faktor seperti dikemukakan Carnrgie dalam (Fadila, 2018); Penyebab pertama adalah a) Faktor Kognitif individu; Kecemasan muncul karena adanya keadaan yang membuat individu merasa takut atau tidak nyaman, sehingga jika pengalaman itu muncul kembali, maka reaksi cemas akan kembali hadir sebagai bentuk manifestasi dari keadaan bahaya yang pernah dirasakan. b) Faktor Lingkungan; penyebab selanjutnya kecemasan bisa muncul karena bersentuhan langsung dengan adat istiadat atau nilai yang dipegang di suatu daerah. Kecemasan dialami individu karena cepatnya perubahan sosial yang secara mendadak dan memungkinkan individu belum siap untuk melakukan perubahan dan tenggelam dalam situasi yang baru dimana hal baru ini terus menerus berubah. Sebagai contoh perubahan masyarakat di saat pandemic Covid19 ini, masyarakat dituntut untuk selalu beradaptasi dengan situasi yang dengan cepat bisa berubah, mulai dari PSBB (Pembatasan Sosial Skala Besar), kemudian beradaptasi dengan kebiasaan baru yang disebut New Normal. Kekuatan terbesar manusia bisa bertahan adalah kemampuannya beradaptasi, namun tidak semua individu beradaptasi dengan kecepatan yang sama. Faktor ketiga adalah c) Faktor Proses belajar; Individu mempelajari hal apa saja yang 
pernah menimbulkan reaksi ketidak nyamanan dan perlahan belajar untuk menyesuaikan diri dengan stimulus tersebut.

Faktor penyebab kecemasan lainnya seperti dijelaskan oleh (Darajat, 2001; Fauzi Ahmad, 2019) adalah sebagai berikut ; a) Perasaan cemas yang muncul akibat merasakan bahaya yang mengintainya. Kecemasan ini lebih kepada perasaan takut yang bersumber dari pikiran dalam dirinya. b) Cemas karena rasa bersalah (guilty feelling) perasaan bersalah dari hati nuraninya, Kecemasan ini kerap mengiringi gejala gangguan mental, yang seringkali nampak dalam bentuk yang umum, c). Kecemasan yang seringkali nampak berbentuk rasa sakit atau penyakit. Kecemasan ini dikarenakan peristiwa yang kurang jelas dan tidak terkait dengan apapun yang terkadang diiringi dengan perasaan takut yang mempengaruhi individu. Kecemasan timbul akibat adanya emosi yang berlebihan.

Isaac dalam (Fadila, 2018), menyebutkan bahwa kecemasan juga bisa diakibatkan oleh 5 faktor : 1 . Usia ; Semakin meninggkatnya usia seseorang maka semakin matang dan berpengalaman pulalah seseorang tersebut, walaupun bukan pedoman yang mutlak. 2. Jenis kelamin; Kecemasan seringkali dialami oleh wanita daripada pria. Peristiwa ini bisa dijelaskan karena perempuan lebih sensitif perasaannya. Laki-laki lebih melihat suatu peristiwa secara global, disisi lain perempuan melihat suatu peristiwa lebih rinci. 3. Pendidikan; tingkat pendidikan individu yang tinggi maka akan mempengaruhi kemampuannya dalam pemecahan masalahnya. 4. Mekanisme koping; Ketika seseorang mengalami kecemasan maka mekanisme koping berperan mengatasinya, jika seseorang kurang mampu melaksanakan mekanisme koping secara konstruktif maka berpeluang terjadi perilaku patologis lainnya. 5. Status Kesehatan; Setelah seseorang memasuki usia lanjut maka akan mulai 
mempunyai penyakit fisik patologis berganda, yang tentu saja berpengaruh terhadap kemampuannya mengatasi kecemasannya.

Penjelasan mengenai kecemasan di atas bisa kita simpulkan bahwa dalam menghadapi kecemasan diperlukan teknik atau cara tertentu agar kita mampu beradaptasi yang lebih dikenal dalam istilah psikologi sebagai psikoterapi. (Sarwono, 2017) menjelaskan bahwa psikoterapi ialah cara intervensi oleh seorang psikoterapis terlatih supaya kliennya dapat mengatasi permasalahannya, dalam hal ini kecemasannya. Sedangkan Psikoterapi Islam adalah pengobatan terhadap gangguan kejiawaan yang bersumber dari dua sumber utama yang paling terpercaya bagi umat Muslim yaitu Al-Qur'an dan Hadist (Sumarni, 2019). Lebih lanjut dijelaskan bahwa tujuan intervensi Psikologi Islam ini adalah untuk memperbaiki kualitas hidup seseorang misal pada kebahagiaan yang dirasakan, resiliensi, kerendahan hati, kekompakan, daya tahan serta ketangguhan semakin meningkat. Disisi lain, bertujuan juga untuk mengurangi bermacam-macam masalah dan persoalan hidup manusia misalnya kecemasan, stres, depresi, dan yang lainnya.

Psikoterapi ialah pengobatan menggunakan metode psikologi untuk masalah yang berhubungan erat terhadap pola pikir, perasaan dan tingkah laku. Psikoterapi (Psychotherapy) terdiri dari dua kata, yaitu "Psyche" yang artinya jiwa, pikiran atau mental dan "Therapy" yang artinya penyembuhan, pengobatan atau perawatan (Amiruddin, 2011). Lebih lanjut dijelaskan pula oleh Ansori dalam (Amiruddin, 2011) bahwa Psikoterapi Islam adalah upaya penyembuhan jiwa (nafs) manusia secara rohaniyyah yang didasarkan pada tuntutan Al-Qur'an dan AlHadis, dengan metode analisis esensial empiris serta ma'rifat terhadap segala yang tampak pada manusia. Bisa ditarik benang merah dari 
$\overline{\text { penjelasan dan penjabaran yang ada, bahwa psikoterapi Islam adalah }}$ upaya penanganan masalah psikologis yang menggunakan metode yang merujuk kepada prinsip-prinsip Islami yang merujuk pada Al-Qur'an dan Al-Hadis.

\section{Metodologi penelitian}

Metode penelitian yang digunakan adalah Literature review atau studi literatur. Adapun dilaksanakan dengan cara mengkaji berbagai teori melalui kepustakaan dari buku, jurnal ilmiah, $e$-book, internet serta bermacam fakta yang ditemukan. Hasil dari berbagai kajian literatur ini digunakan untuk menjelaskan psikoterapi islam yang digunakan dalam mengatasi kecemasan. Adapun langkah-langkah adalah sebagai berikut Penelusuran dilakukan di Garba Rujukan Digital (GARUDA Ristek-Brin). Garuda adalah tempat database elektronik terhadap jurnal, buku dan hasil produk ilmiah lainnya yang diprakarsai oleh Kementrian Ristek Dikti-Brin, peneliti membatasi penelusuran jurnal ilmiah dalam kurun waktu 2017-2020.

\section{Kriteria Seleksi}

Sitematika yang dilakukan peneliti dalam menulis kajian literatur adalah menentukan tema yang akan ditelliti, kemudian melakukan penulusuran dengan tema yang terkait. Berawal dari pencarian jurnal, peneliti peneliti kemudian mereview jurnal dan abstrak dari penelitian guna mencari tahu apakah artikel tersebut layak untuk dikaji. Adapun syarat jurnal yang dianggap layak digunakan adalah: 1) naskah riset yang mengulas mengenai "Kecemasan"; 2) naskah riset yang mengulas tentang pengaruh variabel " $\mathrm{X}$ " terhadap kecemasan dengan memasukkan kata kunci "menurunkan"; 3) naskah yang memuat laporan 
hasil penelitian (original article); 4) peneliti memasukkan kata kunci ke dua yakni "psikologi". Ditemukan sebanyak 304 dokumen; Peneliti mendapatkan 61 naskah yang telah terbit tetapi setelah proses seleksi, hanya 40 naskah publikasi yang layak untuk diteliti. Naskah riset yang lain tidak sesuai karena tidak mengulas tentang pengaruh variabel " $\mathrm{X}$ " terhadap kecemasan.

\section{Analisa}

Pada riset kali ini, peneliti melakukan penyeleksian, evaluasi, dan pemaknaan terhadap semua hasil riset yang sesuai dan erat dengan kecamasan secara isinya. Peneliti memperoleh 40 naskah riset yang sesuai untuk diteliti serta membuatnya menjadi 3 teknik psikoterapi yang paling sering digunakan serta membuat ringkasan hasil riset yang meliputi identitas peneliti, tahun naskah itu terbit, jumlah subjek, alat ukur yang digunakan, dan hasil penelitian. Selanjutnya, peneliti menarik benang merah mengenai teknik psikoterapi yang sering digunakan untuk mengatasi kecemasan, dan perspektif lain yaitu psikoterapi islam apa saja yang digunakan dalam menurunkan kecemasan.

\section{Hasil dan pembahasan}

Hasil penelitian yang akan dibahas pertama kali adalah mengenai bagaimana mengatasi kecemasan dengan psikoterapi pada umumnya. Ada 3 metode psikoterapi yang sering digunakan dalam mengatasi kecemasan, yaitu; Mendengarkan Musik, kemudian hypnosis, serta relaksasi. Kemudian psikoterapi Islam yang sering digunakan untuk mengatasi kecemasan adalah Dzikir, membaca Al-Fatihah serta berdoa dan mendengarkan Murrotal. 
Pembahasan yang pertama menurut penelitian yang dilakukan oleh (Luvita \& Hidajat, 2017) bahwa mendengarkan musik mampu membuat emosi positif seperti bahagia, menumbuhkan motivasi, mengurangi rasa sakit, menambah relaksasi, dan memperbaiki kualitas hidup pada pasien setelah mengalami serangan stroke yang mengalami depresi, merasa tertekan dan mengalami kecemasan. Penelitian ini dilakukan kepada 3 pasien stroke serangan pertama, yang sebelumnya sudah diberikan alat ukur DASS (Depression Anxiety Stress Scale) dan menunjukkan bahwa subjek mengalami penurunan kualitas hidup, namun setelah diberikan terapi dengan mendengarkan musik selama 2 minggu, maka 3 pasien ini mengalami kualitas di beberapa dimensi. Dijelaskan lebih lajut dalam penelitian ini bahwa

Penelitian selanjutnya adalah bagaimana tenik hypnosis berpengaruh terhadap menurunnya kecemasan ibu yang akan melahirkan dengan cara operasi Sectio Caesarea (SC). Penelitian (Fadilah et al., 2018) menjelaskan bahwa, Secara psikis operasi SC berdampak kepada rasa takut dan cemas akan rasa nyeri yang dirasakan selepas efek obat penghilang nyeri menghilang. Namun dengan pemberian terapi hypnosis ini terbukti secara signifikan mengurangi kecemasan ibu yang menjalani proses kelahiran secara SC. Prosedur penelitian dilakukan dengan cara membandingkan dari 30 subjek, dengan kondisi awal 26 tergolong mengalami kecemasan sedang, 2 kecemasan ringan dan 2 mengalami kecemasan berat. Kemudian setelah perlakuan hypnosis, diperoleh hasil bahwa 27 subjek dalam kecemasan sedang dan 3 menjadi kecemasan ringan. keadaan ibu yang fokus dan tenang menjadikan rasa sakit (nyeri), serta semua beban pikiran yang ibu rasakan teralihkan, kemudian ibu mengafirmasikan hal-hal yang positif, itulah alasan kenapa hipnosys dapat mengurangi kecemasan (Fadilah et al., 2018). 
Relaksasi digunakan dalam mengatasi kecemasan dengan tujuan agar menambah kendali dan rasa percaya diri juga menurunkan stres dan kecemasan yang dirasakan pada pasien sebelum operasi. Dalam penelitiannya (Wijayanti, 2018) menggunakan Hamilton Anxiety Rating Scale (HARS), guna mengetahui tingkat kecemasan pasien. Hasil yang diperoleh menunjukkan sebelum mengetahui cara melakukan teknik relaksasi imajinasi terbimbing hamper semua responden berada dikategori cemas dalam tingkat sedang (66,67\%) dan sesudah mendapatkan teknik relaksasi imajinasi terbimbing hamper semua responden berada pada tingkat cemas ringan (66,67\%). Relaksasi adalah cara yang teapat guna meredakan nyeri dan rasa cemas. Relaksasi yang sempurna dapat menurunkan ketegangan otot, kejenuhan, serta rasa cemas. 3 hal pokok dalam melakukan relaksasi ialah sikap yang sesuai, pikiran yang beristirahat, serta keadaan yang menenangkan (Wijayanti, 2018).

Psikoterapi Islam yang digunakan dalam mengatasi kecemasan, hasil dari analisis penelitian ini adalah sebagai berikut;

\section{Dzikir}

Hasil penelitian (Fitriani \& Supradewi, 2019) diperoleh bahwa terapi desensitisasi sistematis dengan relaksasi zikir mampu mengurangi simptom kecemasan fisik dan psikis maka terjadi perbedaan tingkat fobia subjek penelitian, yang awalnya fobia berat menurun ke fobia sedang dan fobia ringan. Sejalan dengan penelitian tersebut dalam kajian literatur yang telah dilakukan diperoleh bahwa (Rahman, 2020) menyebutkan bahwa terapi dzikir mampu mengurangi kecemasan pada ibu hamil. Peristiwa ini disebabkan karena rangkaian terapi dzikir yang menolong individu membangun persepsi dan kepercayaan bahwa semua 
konflik akan mampu dilalui dengan baik atas pertolongan dan ijin dari Allah SWT.

Dzikir mempengaruhi dinamika psikologis seseorang, dapat dijelaskan sebagai berikut; Dzikir diyakini dapat membuat hati menjadi tenang. Ketenangan hati, membuahkan bersihnya pikiran dan sehatnya jasmani. Dzikir akan membawa pemikiran dan kondisi jiwa seseorang menjadi terarah dan seimbang (Sumarni, 2019). Lebih lanjut (Rahman, 2020) menerangkan ketika seorang muslim melazimkan untuk berdzikir, ia akan mendapati dirinya dekat dengan Sang Pencipta, serta merasa dijaga dan memperoleh perlindungan-NYA, lalu akan menimbulkan percaya diri, kekuatan, perasaan aman, tentram dan bahagia. Dzikir bernilai sebagai ibadah serta satu dari berbagai macam cara mendekatkan diri seorang hamba pada Allah SWT, ketenangan saat melakukan dzikir inilah yang mamapu mengurangi kecemasan yang dialami individu. Penelitian menunjukkan bahwa kecemasan pada ibu hamil dapat diturunkan. Adapun kalimat-kalimat dzikir yang dilafazkan ialah kalimat istighfar: "Astagfirullahal'azhiim (saya memohon ampun kepada Allah Yang Maha Agung) dan sholawat. Kalimat dzikir tersebut di ucapkan berulang - ulang dengan tujuan sebagai proses pembelajaran serta melatih semangat pantang menyerah dan kesungguhan demi mendapatkan ridha, cinta Allah SWT.

Terapi ini mampu menghadirkan rasa tumakninah, yaitu perasaan damai dan dan amat nyaman dikarenakan anugerah dari Allah SWT. Dijelaskan lebih mendalam, bahwa pelafalan dan ingatan kepada Allah SWT (dzikrullah) secara berkesinambungan, menciptakan kondisi psikologis yang akan berkembang dalam alam kesadaran, dan memunculkan penjiwaan atas keberadaan Tuhan Yang Maha Pengasih dan Penyayang. Kesadaran ini berpengaruh pada perilakunya, bahwa ia 
mempunyai Allah SWT yang selalu ada. Dzikrullah dengan tutur kata yang lembut dapat memberikan efek relakasasi dan tenteram. Pada pribadi yang demikian rasa cemas dan gelisah tidak akan mengganggunya, justru rasa tenanglah yang meliputinya (Bastaman, 2011).

\section{Membaca Al-Fatihah}

Psikoterapi Islam sering menggunakan perantara Al-Qur'an sebagai alat atau sarana memperoleh kesembuhan (Syifa) untuk permasalahn kesehatan, baik kesehatan fisik maupun psikologis atau pikirannya. Terapi menggunakan Al-Qur'an dibagi menjadi dua yaitu: 1) Fokus yang tinggi saat membaca, memakai pakem atau sesuai aturan yang telah ditentukan. Sebagai contoh seseorang yang membacakan akan memperoleh dampak, baik kepada individu yang membacanya ataupun kepada yang dido'akan dengan wasilah bacaan Al Qur'an. Alunan suara dan tempo yang ditawarkan para sufi pada waktu membaca Al-Qur'an diyakini mampu menghilangkan gangguan jiwa serta mempunyai kekuatan guna menjaga kesehatan jiwa. 2) Mampu mengetahui makna yang ada di dalam ayat-ayat tertentu, sesuai atas apa yang dibutuhkan. Adapun secara teknis, seseorang memulai dengan membaca dan memahami kandungan maknanya (Sumarni, 2019). Dalam jurnal penelitian ini adalah dengan cara membaca Al Fatihah secara reflektif intuitif

Hasil telaah terhadap riset yang dilaksanakan oleh (Julianto et al., 2018) membuktikan bahwa membaca Al Fatihah reflektif intuitif dapat menurunkan kecemasan berbicara di hadapan khalayak ramai pada mahasiswa. Kecemasan mahasiswa cenderung menurun karena bagian otak tertentu terpengaruh oleh hal tersebut sehingga meningkatkan 
neuron serotonergik yang menghambat ketakutan seseorang dan berakhir pada subjek berani untuk berbicara di depan umum.

Penjelasan lebih rinci adalah sebagai berikut, gelombang suara ditangkap oleh otak, melalui terapi membaca Al-Qur'an sel-sel tubuh menjadi aktif sehingga terjadi proses peningkatan absorpsi sel enterochromaffin yang mampu meningkatkan hormon serotonin pada dorsal pariqueductal gray matter. Peningkatan tersebut menyebabkan keadaaan relaksasi sehingga mampu menghambat rasa takut. Selain itu, melalui pengaktifan sel-sel tubuh gelombang suara juga isinya diterima oleh korteks visual primer ditransmisikan ke girus anguler kiri, yang menerjemahkan bentuk visual kata menjadi kode audiotorik dan mentransmisikan ke wernicke's area lalu memicu respon yang tepat masing- masing difasikulus arcuatus, broca's area dan korteks motorik kemudian memunculkan bunyi bicara yang sesuai. Akhirnya dengan proses tersebut dengan media Al Fatihah seseorang berani untuk berbicara di depan umum. (Xiaowei, 2015; Pinel, 2009; (Julianto et al., 2018).

\section{Mendengarkan Murottal dan Doa}

Peneitian (Alivian et al., 2019) dilakukan dengan cara membuat perbandingan (comparative study) akibat dari dua jenis treatment (quasy experiment) yang diberikan pada dua kelompok secara purposive random sampling (mengacak populasi yang sesuai kriteria inklusi). Subjek penelitian diukur sebelum dan sesudah diberikan perlakuan (pre and posttest) guna mengetahui efek dari tiap perlakuan. Penelitian ini dilakukan terhadap pasien yang akan menjalani hemodialisa, berjumlah 30 subjek 15 subjek diberikan perlakuan dengan terapi Murottal dan 15 lainnya dengan terapi Doa. Terapi mendengarkan murottal serta doa 
dari tinjauan statistik sama-sama dapat mengurangi nilai kecemasan pada pasien hemodialisa, tidak ditemukan perbedaan yang signifikan antara terapi murottal dengan terapi doa. Berdoa yang dimaksud dalam penelitian (Alivian et al., 2019) yaitu melekatkan diri kita kepada Allah SWT dengan mendengarkan dan mengucapkan doa dalam hati secara serius dan fokus. Doa adalah suatu perantara penyembuh yang mampu menghadirkan ketenteraman, motivasi positif, pasrah, rasa optimis dan semangat hidup, sehingga sesuai dengan teori penanganan kecemasan yaitu meningkatkan penyesuaian terhadap perasaan tertekan dan terapi psikoreligius.

Menurut tinjauan penulis bahwa membaca doa serta mendengarkan Murottal Al-Qur'an dalam penelitian ini diyakini mampu meresap ke dalam alam sadar dan bawah sadar mahasiswa yang menjadi subjek penelitian. Karena subjek penelitian menjadi sadar akan makna, baik makna secara harafiah akan bacaan yang dibaca namun juga mempengaruhi perilakunya. Hal inilah yang kemudian mengakibatkan timbulnya perasaan tenang, rileks, dan rasa percaya diri. Dalam mengobati atau mengatasi sebuah keluhan dan penyakit selain perlu dipertimbangkan untuk penanganan secara menyeluruh, meliputi semua aspek individu yakni dari sisi biologis (obat dan terapi medis lainnya), psikologis (psikoterapi), sosiologis (Aspek sosial, dukungan keluarga) dan spiritual (keagamaan dengan berdoa atau beribadah) untuk mendapatkan kesembuhan. Pengertian dari doa menurut (Sumarni, 2019) adalah ibadah kepada Allah SWT dengan cara memohon segala harapannya, hanya kepada Nya sesuai dengan perintah-Nya. Doa juga memiliki kekuatan psikospiritual yang terkait erat dengan keyakinan seseorang. Selain diyakini sebagai salah satu bentuk ibadah, berdoa juga merupakan salah satu tuntutnan ibadah yang diajarkan Rasulullah SAW, 
$\overline{\text { sehingga doa selain bernilai sebagai ibadah namun juga sebagai bentuk }}$ pengobatan dari ranah spiritual.

\section{Simpulan}

Kajian-kajian psikologi dibidang psikoterapi islam masih terbilang kurang. Karena ranah penelitian dibidang ini terkadang masih dipersepsikan dengan nuansa tidak ilmiah atau tidak rasional. Padahal jika kita menggunakan metode penelitian yang tepat, maka psikoterapi islam akan berkembang sejajar dengan psikoterapi lainnya. Salah satu faktor penyebabnya karena kurangnya pemahaman mengenai terapiterapi yang ada di dalam Islam itu sendiri. Konsekuensi mengembangkan konsep Psikoterapi Islam akan memunculkan berbagai macam masukkan dan saran untuk pengembangan ke ilmuan yang lebih baik. Kritik dan saran yang ditujukan untuk pengembangan ke ilmuan sebaiknya ditanggapi dengan dalil dan argumentasi secara sistematis bukan dengan sikap emosional. Pembahasan, penelitian, dan pelatihan mengenai psikoterapi islam hendaknya lebih banyak dilaksanakan, agar para pihak yang berkepentingan seperti, mahasiswa, ilmuwan psikologi, dan psikolog mampu mendapatkan tempat pengembangan kompetensi psikoterapi islam. Peningkatan kemampuan ilmuwan psikologi, ataupun psikolog diharapkan dapat secara signifikan mampu meningkatkan pula akan penggunaan, kajian dan penelitian mengenai psikoterapi islam. Tema psikoterapi islam ini menurut tinjauan penulis akan lebih banyak berkembang mengingat banyaknya program studi (prodi) di lingkup PTKIN sudah banyak membuka Prodi Psikologi ataupun Psikologi Islam. 
Daftar Pustaka

Alivian, G. N., Purnawan, I., \& Setiyono, D. (2019). Efektifitas Mendengarkan Murottal Dan Doa Terhadap Penurunan Kecemasan Pada Pasien Hemodialisa Di Rsud Wates. Jurnal Keperawatan Sriwijaya, 6(2), 13-17.

Alwisol. (2008). Psikologi Kepribadian. Universitas Muhammadiyah Malang Pers.

Amiruddin, M. (2011). Psikoterapi dalam perspektif islam. Journal Psikologi Islam, 60-67.

Ahmadiansah, R. (2019). Model Dakwah dalam Pelayanan Pasien. IJIP: Indonesian Journal of Islamic Psychology, 1(2), 215-242.

Bastaman, H. D. (2011). Integrasi Psikologi dengan Islam (F. Nashori (ed.); V). Pustaka Pelajar.

Burger, J. M. (2011). Personality (8e ed.). Wadsworth, Cengage Learning. Cahyandari, R. K. (2019). Peran Spiritual Emotional Freedom Technique dalam Penanganan Nosocomephobia.pdf (pp. 282-303). Prodi $\begin{array}{llll}\text { Tasawuf dan } & \text { Psikoterapi }\end{array}$ https://doi.org/http://dx.doi.org/10.21043/esoterik.v5i2

Darajat, Z. (2001). Pendidikan Agama dan Kesehatan Mental. Bulan Bintang.

Fadila, A. Z. B. (2018). Kecemasan Orangtua menghadapi hospitalisasi anak. Universitas Muhammadiyah Surakarta.

Fadilah, W. N., Megawati, M., \& Astiriyani, E. (2018). Pengaruh Hipnosis Terhadap Tingkat Kecemasan Ibu Post Sectio Caesarea. Media Informasi, 14(2), 148-153. https://doi.org/10.37160/bmi.v14i2.214 
Fauzi Ahmad, S. (2019). Hubungan Kepercayaan Diri dengan Kecemasan dalam Menyelesaikan Skripsi. Universitas Muhammadiyah Surakarta.

Fitriani, A., \& Supradewi, R. (2019). Desensitisasi Sistematis dengan Relaksasi Zikir untuk Mengurangi Gejala Kecemasan pada Kasus Gangguan Fobia. PHILANTHROPY: Journal of Psychology, 3(2), 75. https://doi.org/10.26623/philanthropy.v3i2.1689

Gunarsa, S. D. (2008). Psikologi perawatan. Gunung Mulia. Julianto, V., Indriyani, R., Munir, M. M., Sulantri, C., \& Hasanah, S. M. (2018). Pengaruh Membaca Al Fatihah Reflektif Intuitif terhadap Penurunan Tingkat Kecemasan Berbicara di Depan Umum pada Mahasiswa Prodi Psikologi UIN Sunan Kalijaga Yogyakarta. Jurnal Psikologi, 13(2), 162. https://doi.org/10.24014/jp.v13i2.4299

Kaplan, H.I, Grebb, BA, and Sadock, B. (2010). Klinis., Sinopsis Psikiatri Ilmu Pengetahuan Perilaku Psikiatri (I. M. DR Wiraguna (ed.)). Bina Rupa Aksara.

Luvita, I., \& Hidajat, L. L. (2017). Peran Musik Dan Aspek Kepribadian Terhadap Kualitas Hidup: Studi Kasus Terhadap Tiga Pasien PascaStroke Di Jakarta. Jurnal Psikologi Ulayat, 4(2), 203. https://doi.org/10.24854/jpu22017-105

Mujib, A. (2017). Teori Kepribadian Perspektif Psikologi Islam (2nd ed.). Raja Grafindo Persada.

Nevid, J. S., Rathus, S. A., Greene, B., Murad, J., Medya, R., \& Kristiaji, W. C. (2005). Psikologi abnormal / Jeffrey S. Nevid, Spencer A. Rathus, Beverly Greene; alih bahasa, Tim Fakultas Psikologi Universitas Indonesia, Jeanette Murad ...[et al.]; editor, Ratri Medya, Wisnu C. Kristiaji (Ed. 5). Erlangga. 
Rahman, A. (2020). Terapi Dzikir Dalam Islam Terhadap Tingkat Kecemasan Pada Ibu Hamil. Jurnal Tarbawi, 5(1), 76.

Ramaiah, S. (2003). Kecemasan Begaimana Cara Mengatasi Penyebabnya. Pustaka Obor Populer.

Republika. (2020). Kecemasan Akibat Covid-19 Bentuk Adaptasi Normal. https://republika.co.id/berita/q84alz284/kecemasan-akibatcovid19-bentuk-adaptasi-normal

Rohmadani, Z. V. (2019). Impostor Syndrome Sebagai Mediator Hubungan Antara Religiusitas Dengan Kecemasan Yang Dialami Oleh Mahasiswa Baru. Jurnal Psikologi Integratif, 7(2), 122. https://doi.org/10.14421/jpsi.v7i2.1733

Sarwono, S. W. (2017). Pengantar Psikologi Umum (A. M. Eko (ed.)). Raja Grafindo Persada.

Sumarni. (2019). Proses Penyembuhan Gejala Kejiwaan Berbasis Islamic Intervention of Psychology. Nalar, 3(2), 134-147. https://doi.org/10.23971/njppi.v3i2.1677

Wijayanti, G. S. P. W. (2018). Penurunan Kecemasan Pada Pasien Pre Operasi Setelah Pelaksanaan Relaksasi Imajinasi Terbimbing di Rsud Patut Patuh Patju Gerung. 12(2), 36-43.

Yusuf, S. (2018). Kesehatan Mental Masyarakat Perspektif Psikologi dan Agama (E. Kuswandi (ed.); 1st ed.). PT Remaja Rosdakarya. 